\title{
Negotiations as Double Conflict Unit in Development Practices
}

\author{
Boris I. Khasan* \\ Siberian Federal University \\ 79 Svobodny, Krasnoyarsk, 660041, Russia
}

Received 14.09.2014, received in revised form 21.10.2014, accepted 12.11.2014

The article suggests that traditional understanding of the connection of a conflict and negotiations should be extended by a new scheme, where negotiations are the primary constructively built conflict to achieve such a product as an agreement (contract), which would regulate contradictions of the future, planned (designed) interaction of the participants. Therefore, negotiations are a specific coordinated game of the participants, when all versions of possible conflicts are played in order to prevent their destructive scenarios.

Keywords: conflict, negotiations, conflict constructions, game scenario, educational practice, ability to negotiate, agreement.

Research area: psychology.

I dreamed that $X$ expressed some unkempt thought. It followed from his situation, was in harmony with his ideals, stemmed from his charming unintelligent character. In the morning there was a problem: was this thought his or mine?

Stanislaw Jerzy Lec

In normal practice, negotiations appear as an institution of conflict resolution and conflict relationships' regulation, i.e. the negotiation process itself is either preceded by conflict or this conflict exists as a subject of the current regulation. In the second case, the negotiations are arranged as if over conflict. Thus, the negotiations are separated from the conflict and, at best, treated as the final or reflexive stage of the conflict. However, the experience of human interaction rather clearly shows other types of relationships of these phenomena. Namely, the negotiations are in fact the primary constructive conflict, which is aimed at achieving such a result as an agreement (contract), regulating confrontations of the future and planned (projected) interaction between participants.

In this regard, a constructive character and a productive result of the interaction obviously depend on the quality of the negotiations in the conflict structure, where future cooperation should be imagined in a certain scenario

(C) Siberian Federal University. All rights reserved

* Corresponding author E-mail address: khbi@ippd.ru 
incarnation. Thus, the negotiations represent a kind of specially coordinated game of the participants, in which possible conflict games are played out for the sake of a kind of prophylaxis (prevention) of their destructive scenarios.

It is clear that in such negotiations traditional components of this institution (subject object, agenda, BATNA) are supplemented by actualization of the projected conflict scenes, which, in turn, require participants to be especially careful. In other words, the fact that participants generally tend to avoid conflict provocation should be presented in a special way in the form of a special unit in the negotiation process for ensuring the future cooperation between the parties in a constructive and productive interaction.

Therefore, the usual traditional rules of negotiations process, relating to the preliminary approvals (negotiations about negotiations, negotiations about the procedure, substantive negotiations) include also to the need to discuss the rules of handling and realization of additional conflict situation, which is a conflict in the conflict. This means that if the participants understand that the institution of negotiations is itself a cultural conflict structure (if we resort to an analogy, it is the same as a chess game), they now need to have an understanding of and a competence in "fitting inside" the conflict structure of the conflict components, modeled for their prevention.

Thus, I suggest once again try to overcome the habitual and stereotypical view of the combination of conflict and negotiations as the conjugate relationship of the "problem-solution" type and treat them instead as "the solution at the expense of relationship: task 1 - task 2 ".

\section{II}

For example, I intend to present here a brief description of one of the plenty attempts to take the "challenge" of the époque and initiate a new form of educational practice. This project, like many others, was in the active form only for a while and has not turned into practice. Why has it happened?

In 1995, on the base of the experimental school №106 in Krasnoyarsk (currently it is a gymnasium "Universe") there was made and implemented a project of creating child-adult publicorganization"Worldwithoutconfrontation". Authors of the project have been thinking that the strongest challenge of the end of the $20^{\text {th }}$ century is the sharpening contradiction between globalization, integration, increasing mobility, information processes on the one hand and the unresolved conflict incompetence in almost all spheres of public life on the other hand. The scale and diversity of this kind a challenge implied that the ways to resolve this problem should be found in education. The core idea of the project was a consideration that many social conflicts have devastating influence due to incompetence of the participants in bringing about constructive interaction processes. The formation of a competence under certain educational conditions at a certain sensitive age should have been done through the implementation of two interrelated processes. There should have been the tradition of transfer of knowledge about conflicts, their nature and appropriate ways of their resolution and there should have been created children and adult nongovernmental organization whose mission would be the practice of joint negotiation mode of actual conflicts' settlement, which teenagers face in their training and other social relations [Khasan, 2001].

As always, the enthusiasm of the founders of this project has provided the visibility of success. There were created several organization's subsidiaries in a number of city schools, which made it possible to register the organization as a city one in 1997. They started real teaching school and college students, who were the members of the organization in the field of mediation. 
Here is how the Charter of WWC (world without confrontation) describes the activities of the organization:

$<\ldots>4$.2. The organization has the following types of active participation, determined by the extent of the conflict competence:

A) first level of participation - mobile participation - active intervention in the current destructive conflicts with a proposal to help WWC with the analysis and resolving ongoing conflicts;

B) second level of participation-participation as a mediator - direct assistance to the conflicting parties in non-violent forms of negotiation to resolve any existing or potential conflicts;

B) third level of participation - supervising (professional -competent- responsible) participation - the analysis of existing and the development of promising methods of non-violent conflict resolution, and teaching these methods to members of the organization and anybody who wishes [Charter of the Krasnoyarsk city children NGO "World without confrontation", registered in the Department of Justice of Administration of the Krasnoyarsk Territory on 10.07. 1997].

During the first 3 years the organization could initiate several negotiation processes: to resolve interpersonal conflicts of teenagers; to resolve conflicts between a teacher and a group of students; between parents, school officials and students as direct participants in the conflict. As a rule, each time all such processes (the organization file has a little over 30 of such cases) were organized as independent actions, accompanied not only by a serious preparation by members of the organization, but also by considerable and special work to overcome the resistance of conflicting parties to such extraordinary forms of their settlement. Such work has always demanded significant time-consuming tasks and serious mobilization of psychological resources. After some time, the share of the negotiating process itself was reduced to single cases, the main content of the activities was case studies work of members of the organization and training with simulation models, as well as various social and educational activities of mainly preventive character. Gradually the theme of negotiations and direct dealing with real conflicts' resolution became "the thing of the past", being included as an integral part in other social projects [Khasan, 2003].

So, we can say that the project idea was not put into practice, despite the attempt of its institutionalization. Is this fact sufficient to call the project as a failure?

Let us not hurry. We should recall the classic works on psychology. Already in the 30s of the last century E. Stern wrote the following:

Even if the youth organization falls apart after a year, leaving no trace of their activities; it still has not existed in vain, for the participants were developing their desire to fight; they learned not only to theoretically understand public relationships and interactions, but also to assimilate them by their feelings and will.

Considering this kind of youth associations aimless and unnecessary on the grounds that they have "no sense", that they have "no stable character", that they "lead to a waste of time" is at least as flimsy as if someone found children sandcastles meaningless on the ground that the first wind would destroy these constructions.

From this perspective, one needs to distinguish youth movement and school selfgovernment. Superficial approach concerns mainly a discrepancy between great intentions and actual results; but a deeper glance will help to understand that the true meaning of this activity is largely just external lack of results. If from the beginning means and goals matched perfectly, then everything had to be reduced to a simple transfer and imitation of behaviors 
existing among adults. But it would be something quite unlike the youth.

As a young man seeks to rise above the level of the previous generation, because he wants to achieve new goals by new means, since he wishes to recreate even old and eternal things from the inner self, since these roaming, search for and going through a hundred disappointments is a prerequisite to reach in the end a good consistency of means and goals, the will and abilities [Stern].

Despite full agreement with this classic statement, which would have seemed to soothe the feelings of the authors of the project, I should notice that in addition to the psychological and pedagogical meanings this kind of enterprise had also a claim to create an educational social practice, new not only for young people, but for the whole education system, as the response to the indicated earlier in this paper challenge. This means that a simple understanding of some natural law in the dynamics of this initiative requires an understanding of what circumstances were unaccounted for by the authors of the project in an attempt to find (despite some natural reasons) a path from the initiation and realization of an ability to negotiate to the construction of social practices, which is to form the relevant competence on the basis of this ability.

The importance of this work on understanding is also due to the fact that in recent years the idea of school mediation has been actively and persistently promoted; this idea is positioned as a new technology for some reason. In the ideology of these "new" initiatives for education can be easily read the same important setting to overcome the tradition of using force to resolve conflicts as it inevitably contradicts really new social and cultural trends. And, at the same time, the attention is drawn to certain "copying" the "adult" forms of alternative dispute resolution with some age-adjusted performance, of course.

\section{III}

For this kind of work, we need to determine the ideas about, in the first place, natural and artificial components of the phenomenon, which we tried to exploit in the attempts to construct a practice; secondly, we should take into account the institutional conditions and their phase characteristics, which correspond to the projected outcomes.

The ability to negotiate implies the ability to interact with the setting at reaching an agreement.

This ability has undoubtedly a social nature and is realized in its original and genetic form literally with the first signs of autonomous and at the same time dependent behavior. The examples of such signs appear in all the plots of exchange relations. In early childhood, these are the subjects of "nutrition" and "hygiene"; then "order" in playing with toys; treat; time to play, walk, etc. All these are given in exchange for... Similar stories are realized later in the children community. All, without exception, child psychologists indirectly fix this ability - to enter into exchange relations with the prospect to get specific "benefits". Ie.O. Smirnova emphasizes that the child's "Self", acquiring a thing character in these activities, appears as an object, not coinciding with the child. This means that children are already able to carry out elementary reflection that takes place not in the interior, perfect plan, as an act of self-analysis, but has an expanded exterior evaluation of their own achievements or comparison their estimates with those of others, and thus contrasting themselves to other people.

The formation of such a system of "Self", where the starting point is an achievements, estimated by the environment, marks the transition to the preschool years" [Smirnova]. This new acquisition of a certain age period is mastered and then institutionalized in the plot- 
role-playing game, where the ability to negotiate is in maximum demand, actively maintained and actually gains the status, constituting children community [Shchedrovitskii].

It turns out that the very phenomenology of "negotiationableness" and its certain success of "embeddedness" in both child-adult relations and inter-personal at least during the preschool years are quite obvious and may be defined as quite natural. However, is this potential resource developed by institutional structures of further education and the question is whether they can contribute to its building in special cultural forms-means?

Nothing similar can be found in the descriptions of primary school age, particularly in the context of traditional teaching, where the discipline and strictly hierarchical relationships are in the first place. All stories of agreements fall back in the "non-principal segments of life", as the main aim is defined as an educational positioning. This means that the child has no longer a chance to assess their own success and certainly can not act an authority indicating their own interests. And this happens despite the declaration of academic subjectivity. A miraculous exception is a book by V. Maksakova and L. Semina. "Learning to negotiate (I, you, we) for 1-2 grades of primary school". Authors easily find options for negotiating processes in the school life of children and offer completely age-appropriate schemes how to work on developing the ability to negotiate and corresponding competence [Maksakova, Semina].

Without a doubt, the most sensitive age of appeal to realize the ability to negotiate is adolescence. There is already a myriad of topics for discussion, not only because the activity range is widened, but also there are serious reflexive resources and a lot of claims to the autonomization and co-operation in connection with the known identity processes (See, for example, Nartova-Bochaver). And once again, a modern teenager "passes by" institutions of negotiations during their main forms of activity. We cannot say, however, that no attempt was made in particular schools and publications. In fact, this issue has led to creating schoollaboratory of self-determination, founded by Alexander Naumovich Tubel'skii [Tubelskii]. In Krasnoyarsk gymnasium "Univers", Anna Vladimirovna Dorokhova and I initiated a project of a special course for teens "Interests. Values. Norms" [Dorokhova, Khasan]. Nonetheless, all these facts can be regarded as more or less successful precedents, localized in individual schools or in small online communities, not having impacted so far the educational practices in the field as a whole.

The next stage of education - high school consistently retains paternalistic traditions, without offering any realistic options of agreements even with respect to individual, popular educational programs. In all known cases, the school student acts as a petitioner and consumer, but not as a subject of the interaction, not as an equal party in the relations.

Thus, modern educational reality in its well-established institutional forms actually ignores the fact, which we define as a challenge. Lacking institutional support the ability to negotiate remains in its rudimentary forms and easily gives way to a manipulative, power schemes of interaction, i.e. it avoids the development and does not feel opportunities in a new practice.

It could seem that in these circumstances compensatory projects such as "World without confrontation" and/or modern "School services of conciliation and mediation" are designed just to solve, bypassing stubborn paternalistic tradition, the task of realizing the ability to negotiate and its building in the negotiating competence through this kind of institutional form. 
IV

The negotiating competence is the condition of a new socio-cultural practice, in which the institutional form of reaching agreements and their joint implementation become the dominant social reality as opposed to modern one, in which forcing "correct" behavior dominates. In the tradition, people act together and to some extent consistently in cases, if the otherwise threatens their well-being, and in circumstances, if this "threatening otherwise" situation becomes acute. And this happens not because people understand and accept the interests of others, preferring autonomy to integration. In other words, modern social relations are largely determined by protective motives and aspirations to achieve separate goals through other forms of coercion with various degrees of intensity, i.e. with the use of force. Apparently, four centuries' reliance on social contract theory requires serious reinforcements at real human relationships' level and also its procedural realization.

While it turns out that we have not built a new practice, but actually mounted the old traditions in the new generation, technical equipping and perfecting these traditions on the basis of fairly traditional technological schemes for conflict resolution, only by placing them in the school space.

The ability to negotiate is grown, and then formed through participation in institutionalized forms of activity.

These forms should not have exclusive nature, as it was in our project "World without confrontation", the negotiating activities in which happened not on the initiative of the participants and only after or right before an impending conflict, i.e. when the participants have already had some destructive experiences. Even adults find difficult to handle this kind of experience and for children it is a super effort.
In the so-called reconciliation services, as the name suggests, the action follows the appearance of signs or real relations of hostility, i.e. as well as in our project the cases themselves, which are the subject of negotiations, are not luckily massive and even systematic. So, if you rely solely on efforts to resolve (settle) already existing conflicts, one can hardly expect a systematic and subject-differentiating activity, and this in turn means that the process of competence formation becomes questionable, and the activity of this kind of the institution will have to either look for compensatory form or to turn into a simulation.

These forms should not be based exclusively on overcoming destructive processes, otherwise there is a risk of attributing negotiation and conciliation processes solely to conflict situations, whereas cooperative, integrative forms of interaction occur and form as forecasting any kind of relapse. So, if you rely solely on efforts to resolve (settle) already existing conflict (or rather acute phenomena), you can form a certain type of personal deformation and instead of the negotiating competence get the effects of social negativity.

So, here are some of the results of the described experiment:

- each child has the ability to negotiate, of course, with the individual uniqueness;

- the ability to negotiate demands its actualization and appropriate to age period formation in terms of educational levels;

- to grow the ability to negotiate into the proper competence there should be necessary institutional conditions, in which the parties should develop and use special interaction technologies and make real agreements;

- the negotiable subject in terms of education should be both game and 
real situations, involving cooperative and integrative activity forms with the corresponding length, clear results and full responsibility of the parties;
- the negotiations to resolve the conflict, which have already occurred, are rather additional than the basic activity form of the relevant institutions.

\section{References}

1. Khasan, B.I., Khromchenko, M.S. A world without confrontation or "Long live the conflict!". M. Bonfi, 2001.

2. Khasan, B.I., Diundik, N.N., Fedorenko, Ie.Iu., Kukharenko, I.A., Privalikhina, T.I. Prevention of unfreedom. Organizational and methodological guidelines. M.; Bonfi, 2003.

3. Stern E. Serious game in adolescence. Pedology of the youth. Ed. by I. Ariamov. Uchpedgiz. Moscow-Leningrad, 1931.

4. Smirnova, Ie.O. Child psychology. M. Shkola-Press, 1997.

5. Shchedrovitskii, G.P. Game and child society. Selected Works. M., 1995.

6. Maksakova, V., Semina L. Learning to negotiate. M., Magister,1998. Available at: http:// school-sector.relarn.ru/prava/school/classes/1-2/

7. Nartova-Bochaver, S.K. Sovereign human. Psychological study of the subject in their being. Piter, 2012.

8. Tubelskii, A.N. Legal space at school. M., Miros, 2001.

9. Dorokhova, A.V., Khasan, B.I. [Modern Humanology at school. M., Miros, 2001.

\section{Переговоры - двойная конфликтная конструкция в практиках развития}

Б.И. Хасан

Сибирский федеральный университет Россия, 660041, Красноярск, пр. Свободный, 79

Традиционные представления о связи конфликта и переговоров предлагается расширить новой схемой, в которой собственно переговоры представляют собой первичный конструктивно построенный конфликт для достижения такого продукта, как согламение (контракт), которым регулируются противоречия будущего, планируемого (проектируемого) взаимодействия участников. Таким образом, переговоры представляют собой своеобразную, специально согласованную игру участников, в которой разыгрываются варианты возможных конфликтов для своеобразной профилактики (превенции) их деструктивных сценариев.

Ключевые слова: конфликт, переговоры, конфликтные конструкиии, игровой сиенарий, образовательная практика, переговороспособность, согламение.

Научная спещиальность: 19.00.00 - психологические науки. 